\title{
Inhibition of aquaporins as a potential adjunct to breast cancer cryotherapy
}

\author{
HAIFA ALKHALIFA ${ }^{1,2}$, FATIMA MOHAMMED ${ }^{1}$, SEBASTIEN TAURIN $^{3}$, \\ KHALED GREISH $^{3}$, SAFA TAHA ${ }^{3}$ and SALIM FREDERICKS ${ }^{1}$
}

\begin{abstract}
${ }^{1}$ Department of Basic Medical Sciences, Royal College of Surgeons in Ireland, Medical University of Bahrain, Adliya 15503, Kingdom of Bahrain; ${ }^{2}$ Department of Science, New York University Abu Dhabi, Abu Dhabi 129188, United Arab Emirates; ${ }^{3}$ Department of Molecular Medicine, College of Medicine and Medical Sciences, Princess Al-Jawhara Centre for Molecular Medicine, Arabian Gulf University, Segaya, Manama 328, Kingdom of Bahrain
\end{abstract}

Received September 24, 2020; Accepted March 2, 2021

DOI: 10.3892/ol.2021.12719

\begin{abstract}
Cryoablation is an emerging type of treatment for cancer. The sensitization of tumors using cryosensitizing agents prior to treatment enhances ablation efficiency and may improve clinical outcomes. Water efflux, which is regulated by aquaporin channels, contributes to cancer cell damage achieved through cryoablation. An increase in aquaporin (AQP) 3 is cryoprotective, whereas its inhibition augments cryodamage. The present study aimed to investigate aquaporin (AQP1, AQP3 and AQP5) gene expression and cellular localization in response to cryoinjury. Cultured breast cancer cells (MDA-MB-231 and MCF-7) were exposed to freezing to induce cryoinjury. RNA and protein extracts were then analyzed using reverse transcription-quantitative PCR and western blotting, respectively. Localization of aquaporins was studied using immunocytochemistry. Additionally, cells were transfected with small interfering RNA to silence aquaporin gene expression and cell viability was assessed using the Sulforhodamine B assay. Cryoinjury did not influence gene expression of AQPs, except for a 4-fold increase of AQP1 expression in MDA-MD-231 cells. There were no clear differences in AQP protein expression for either cell lines upon exposure to frozen and non-frozen temperatures, with the exception of fainter AQP5 bands for non-frozen MCF-7 cells. The exposure of cancer cells to freezing temperatures altered the localization of AQP1 and AQP3 proteins in both MCF-7 and MDA-MD-231 cells. The silencing of AQP1, AQP3 and AQP5 exacerbated MDA-MD-231 cell damage associated with freezing compared with control siRNA. This was also observed with AQP3 and AQP5 silencing in MCF-7 cells.
\end{abstract}

Correspondence to: Dr Salim Fredericks, Department of Basic Medical Sciences, Royal College of Surgeons in Ireland, Medical University of Bahrain, Adliya 15503, Kingdom of Bahrain

E-mail: sfredericks@rcsi-mub.com

Key words: breast cancer, cryoinjury, cryotherapy, aquaporins, cryosensitization
Inhibition of aquaporins may potentially enhance cryoinjury. This cryosensitizing process may be used as an adjunct to breast cancer cryotherapy, especially in the border area targeted by cryoablation where freezing temperatures are not cold enough to induce cellular damage.

\section{Introduction}

Cancer is a leading cause of mortality and morbidity, with 9.6 million cancer-related deaths in 2018 worldwide (1), and approximately 18.1 million newly diagnosed cancer cases (2). Patients with cancer currently have multiple treatment options available, including surgery, cytotoxic-chemotherapy, radiotherapy and immunotherapy $(3,4)$, as well as cryoablation, which is considered a treatment option for certain types of cancer (5). It is most commonly used to treat liver, kidney, lung, prostate and breast cancer (6). This minimally invasive percutaneous procedure is emerging as an alternative to surgery in patients with early-stage breast cancer (7). Although cryoablation has yet to be established as a standard-of-care procedure for breast cancer management, it should be considered an appropriate therapy during periods where there are changes in standard procedures due to shifts in healthcare policies and practices $(8,9)$. It was argued that this non-operative, resource-saving strategy was pragmatic and appropriate for managing localized breast cancer during the height of the 2020 COVID-19 pandemic (9).

Cryoablation is a percutaneous ablation technique that targets neoplastic tissue destruction through freeze/thaw cycles at low temperatures $(5,10)$. The process involves inserting a cryoprobe into a tumor mass guided by imaging devices $(6,11,12)$. Once the lesion is targeted, the cryoprobe is cooled by passing liquified gas through the probe, which expands into a gaseous state at the tip to create low temperatures $<-40^{\circ} \mathrm{C}(5,13)$. In clinical cryoablation, temperatures below $-40^{\circ} \mathrm{C}$ are maintained to eradicate all cancer cells (12). Multiple freeze-thaw cycles are performed to obtain an effective ablation (13). This approach for nodule destruction does not allow time for defensive mutations to occur in cancer cells (14). The delivery of cryotherapy, combined with the anatomy of the breast presents technical challenges for its clinical application (10). 
Achieving critically low temperatures throughout the entire tumor mass is difficult (12). The thermal gradient that spreads out from the inserted freezing probe may not fully and completely penetrate the entire mass of the tumor with the desired freezing temperature (12). In addition, proximity to blood vessels can interfere with the freezing process (15). Hence, the destruction of tumor cells may not be achieved at the freeze margin. Incomplete ablation of cancerous tissue results in therapeutic failure (12). The sensitization of cells to freezing has been suggested as a way to overcome the problem of under-freezing at the freeze margin $(16,17)$. Previous studies have revealed the synergistic effect of administering cryosensitizing agents, such as 5-fluorouracil, vitamin D3 and cisplatin prior to cryotherapy to improve ablation efficiency (18-20). The aim of cryosensitization as an adjunct to cryoablation, is to increase the ablated area achieved by each freeze-thaw cycle (21). Cellular injury resulting from both freezing and thawing is associated not merely with simple freeze rupture but also with molecular-based cell death processes (apoptosis, autophagy and necrosis) as well as immune responses to cell damage (17). Therefore, ablation could be augmented with the use adjuvants, such as pro-apoptotic, pro-inflammatory and antiproliferative chemicals (17). The use of cryosensitizing agents and the ensuing cellular damage results in biochemical events associated with cell death $(13,17)$.

There is a clinical need to enhance the efficacy of cryotherapy using adjunctive cryosensitizing agents and the candidate agents are diverse (12). Cellular damage resulting from freezing involves various processes that could be considered targets for cryosensitizing agents (17). These processes include both structural stress events, such as rupture of membranes and cytoskeletal disassembly and chemical stress events, such as metabolic uncoupling, ATP depletion, ionic imbalances, cellular acidosis and free radical generation (17). When freezing is initiated, ice formation creates a hyperosmolar extracellular environment, which draws water out of the cell and in turn causes cellular dehydration $(7,11,17)$. This exposes cells to potentially lethal osmotic pressures $(14,15)$. Central to this cellular passage of water are the aquaporin (AQP) integral proteins (22). These transmembrane channels allow water to flow through cell membranes in response to osmotic gradients in cells (23). The presence of AQPs increases plasma membrane permeability to water by $5-50$ times compared with that of the plasma membrane alone (24). Freezing of cancer cells in vivo has been demonstrated to induce an increase in the expression of AQP3 and this has been suggested to be an underlying mechanism for overcoming osmotic stress created by the formation of ice crystals outside the cell and the subsequent movement of water from the interior to the exterior of the cell (22). In relation to cold temperature stress, AQP proteins may be considered cryoprotective (25-28). Hence, AQP proteins are potential pharmacological targets for enhancing the efficiency of cryotherapy (22).

AQP proteins are localized to the cytosol of cancer cells in vivo (29-31). However, these proteins must be precisely positioned in the plasma membrane in order to function as transporters (22). In prostate cancer cells, AQP3 has been found to translocate from the cytosol to the plasma membrane in response to cryoinjury (22). This cellular localization process involves a dynamic sequential cascade of events from transcription to translation and post-translational modifications followed by recruitment as vesicular cargo transported to appropriate plasma membrane domains and finally ending in precise docking and fusion with the cell membranes (29-31). These complex events are induced as part of the adaptation mechanisms to cryoinjury (32). In vitro interference with any of these cellular events may alter AQP function and, in turn, alter cellular adaptation to freezing temperatures (22). Blockade of AQP activity may therefore be a cryosensitizing process, i.e., inhibition of AQPs may enhance the damage caused by freezing (17). An increase in AQP3 activity is cryoprotective, while inhibition of AQP3 has been demonstrated to increase cryodamage $(22,26,33)$. However, to the best of our knowledge the role of AQP activity in human breast cancer cells has not been reported in relation to cryoinjury.

Breast cancer cells express AQP1, AQP3 and AQP5, and it has been reported that this expression is associated with severity of histological tumors and patient prognosis (34). It has been demonstrated that AQP3 has a key role in the migration of breast cancer cells (35), and it has been further suggested that the level of increased expression of AQP3 and AQP5 may serve as biomarkers of cancer severity (36). AQP1 expression is significantly associated with poor clinical prognosis amongst patients with early breast cancer $(37,38)$. Disease severity is related to various subtypes of breast cancer, which are classified based upon defined features (39-41). Triple-negative breast cancer (TNBC) is characterized by the absence of estrogen receptors (ER) and progesterone receptors (PR) and a lack of excess human epidermal growth factor receptor-2 (HER2). Clinically TNBC is associated with poorer prognosis compared with non-TNBC types of breast cancer (42-45). TNBC is also associated with the upregulation of AQP3 and AQP5 (36). MDA-MB-231 is a TNBC cell line that is used as an in vitro model of TNBC $(46,47)$. In contrast, MCF-7 cells express ER, PR and low levels of HER2 and are used as an in vitro model of hormone-responsive breast cancer types (48). The utilization of these 2 cell lines in experiments allows for the comparison of both breast cancer types (49-52).

It was hypothesized that the inhibition of AQPs may function as a possible adjuvant process to cryotherapy that may enhance cryoablation. The current study aimed to investigate changes in AQP gene expression and cellular localization of AQPs in response to cryoinjury. This was performed using 2 breast cancer cell lines (MDA-MB-231 and MCF-7). In addition, the current study investigated the synergistic antitumor effect of cryoinjury in conjunction with aquaporin blockade on breast cancer cells. The findings of the present study reported a synergy that may bring about a cryosensitization which may be used as an adjunct to cryotherapy. This has particular therapeutic importance in the border area targeted by cryoablation where freezing temperatures are not cold enough to induce cellular damage.

\section{Materials and methods}

Cell culture. Human breast cancer cell lines MDA-MB-231 and MCF-7 were obtained from the American Type Culture Collection. Cells were cultured in advanced Dulbecco's modified Eagle's medium (Advanced DMEM; cat. no. 12491015; Thermo Fisher Scientific, Inc.) supplemented with $2.5 \%$ 
Table I. Forward and reverse primer sequences used for RT-qPCR.

Gene

Forward Primer (5'-3')
Reverse Primer (5'-3')

GGTTAATCCCACAGCCAGTGTAG TTGTCGGCGAAGTGCCAGATTG AGTCAGTGGAGGCGAAGATGCA ACCACCCTGTTGCTGTAGCCAA
AQP1

AQP3

AQP5

GAPDH

\author{
TATGCGTGCTGGCTACTACCGA \\ CCGTGACCTTTGCCATGTGCTT \\ TACGGTGTGGCACCGCTCAATG \\ GTCTCCTCTGACTTCAACAGCG
}

RT-q, reverse transcription-quantitative; AQP, aquaporin.

fetal bovine serum (FBS; cat. no. F2442; Sigma-Aldrich; Merck $\mathrm{KGaA}$ ), $1 \% 10,000 \mathrm{U} / \mathrm{ml}$ penicillin $\mathrm{G}$ sodium salt $/ 10 \mathrm{mg} / \mathrm{ml}$ streptomycin sulphate (cat. no. 15070063; Thermo Fisher Scientific, Inc.) and 1\% 200 mM L-glutamine (cat. no. G7513; Sigma-Aldrich; Merck KGaA) and maintained at $37^{\circ} \mathrm{C}$ in a humidified atmosphere containing $5 \% \mathrm{CO}_{2}$.

Cryoinjury. MDA-MB-231 and MCF-7 cells were placed at $-13,0$ or $37^{\circ} \mathrm{C}$ for $10 \mathrm{~min}$. The lowest temperature that could be used to accomplish freezing while maintaining cell viability was $-13^{\circ} \mathrm{C}$. In a previous study, a temperature of $-10^{\circ} \mathrm{C}$ resulted in a high cell survival rate, whereas $-15^{\circ} \mathrm{C}$ led to $>80 \%$ cell death (53). In addition, $0^{\circ} \mathrm{C}$ degree was used as the control temperature for non-freezing conditions. Freezing for $10 \mathrm{~min}$ was the time necessary for the media to be frozen while preserving the integrity of the cells (53). A temperature of $0^{\circ} \mathrm{C}$ was achieved by placing the cells on a MyBlock ${ }^{\mathrm{TM}}$ Mini dry bath with cooling (Benchmark Scientific, Inc.) and $-13^{\circ} \mathrm{C}$ temperature was achieved by placing the cells in a Sanyo temperature calibrated freezer (Sanyo Electrical Co. Ltd.), while the control temperature was achieved by maintaining the cells in a humidified $5 \% \mathrm{CO}_{2}$ atmosphere at $37^{\circ} \mathrm{C}$. After cold exposure of $-13^{\circ} \mathrm{C}$ and $0^{\circ} \mathrm{C}$ temperatures, cells were placed back in a humidified $5 \% \mathrm{CO}_{2}$ atmosphere at $37^{\circ} \mathrm{C}$ for either 2,6 or $24 \mathrm{~h}$.

Cell treatment and collection for RNA and protein analysis. Expression levels of AQP1, AQP3 and AQP5 were assessed by seeding $1 \times 10^{6}$ cells in $60-\mathrm{mm}$ tissue culture dishes. After $24 \mathrm{~h}$, cells were exposed to either- 13,0 or $37^{\circ} \mathrm{C}$ for $10 \mathrm{~min}$ and placed back at $37^{\circ} \mathrm{C}$ in a humidified atmosphere containing $5 \%$ $\mathrm{CO}_{2}$. Cells were collected after 2, 6 and $24 \mathrm{~h}$ incubation. Cells were scraped and pelleted by centrifugation at $238 \mathrm{x}$ g for $5 \mathrm{~min}$ at $4^{\circ} \mathrm{C}$ and then washed twice with phosphate-buffered saline (PBS; Sigma-Aldrich; Merck KGaA). The pellet was subsequently used for RNA or protein extraction.

RNA extraction and cDNA synthesis. Total RNA was isolated using the RNeasy Mini kit (Qiagen $\mathrm{GmbH}$ ) according to the manufacturer's instructions. RNA concentration and purity were measured spectrophotometrically at 260 and $280 \mathrm{~nm}$ using a NanoDrop ${ }^{\mathrm{TM}} 2000$ (Thermo Fisher Scientific, Inc.). cDNA was synthesized using the High-Capacity cDNA Reverse Transcription kit (Applied Biosystems; Thermo Fisher Scientific, Inc.) according to the manufacturer's protocols. Each reaction consisted of $1 \mu \mathrm{g}$ total RNA, $2 \mu \mathrm{l}$ RT buffer, $2 \mu \mathrm{l}$ random primer, $0.8 \mu \mathrm{l} \mathrm{dNTP}, 1 \mu \mathrm{l}$ MultiScribe ${ }^{\mathrm{TM}}$ reverse transcriptase and $20 \mu \mathrm{l}$ QSP of nuclease-free water. Reverse transcription conditions were as follows: $25^{\circ} \mathrm{C}$ for $10 \mathrm{~min}$, $37^{\circ} \mathrm{C}$ for $120 \mathrm{~min}$ and then $85^{\circ} \mathrm{C}$ for $5 \mathrm{~min}$.

Reverse transcription-quantitative $(R T-q)$ PCR. RT-qPCR was performed to determine the mRNA expression levels of AQP1, AQP3 and AQP5, which were normalized to GAPDH expression. Primers were synthesized by Macrogen, Inc., as shown in Table I. A reaction volume of $20 \mu \mathrm{l}$, which included $1 \mu \mathrm{l}$ cDNA, $25 \mathrm{nmol}$ forward and reverse primers, $7 \mu \mathrm{l}$ nuclease-free water and $10 \mu 1 \mathrm{SYBR}^{\mathrm{TM}}$ Green PCR Master mix (Applied Biosystems; Thermo Fisher Scientific, Inc.) was used. Each reaction was run in duplicate on the Applied Biosystem 7500 system (Applied Biosystems; Thermo Fisher Scientific, Inc.) in MicroAmp ${ }^{\mathrm{TM}}$ Optical 96-well reaction plates (Applied Biosystems; Thermo Fisher Scientific, Inc.). Samples were initially denatured for $10 \mathrm{~min}$ at $95^{\circ} \mathrm{C}$, each cycle was $15 \mathrm{sec}$ at $95^{\circ} \mathrm{C}$, followed by annealing and elongation for $1 \mathrm{~min}$ at $60^{\circ} \mathrm{C}$ for 50 cycles. Relative gene expression was represented by fold-change relative to GAPDH. This fold-change was calculated based on the threshold cycle $(\mathrm{Ct})$ using the $2^{-\Delta \Delta \mathrm{Cq}}$ method (54). Fold-change was defined as the normalized gene expression $\left(2^{-\Delta \mathrm{Cq}}\right)$ in the test sample/by the normalized gene expression $\left(2^{-\Delta \mathrm{Cq}}\right)$ in the control sample (vehicle).

Western blotting. Cell pellets were lysed in a protein extraction buffer composed of $150 \mathrm{mM} \mathrm{NaCl}, 50 \mathrm{mM}$ Tris $\mathrm{HCl}$, $1 \mathrm{mM}$ ethylenediaminetetraacetic acid, $10 \%$ glycerol, $1 \%$ Triton-X-100, $0.5 \%$ sodium deoxycholate and $0.1 \%$ sodium dodecyl sulphate (SDS) supplemented with $1 \mathrm{X}$ protease inhibitor cocktail (Sigma-Aldrich; Merck KGaA), 2 mM phenylmethanesulfonylfluoride and $0.01 \mathrm{M}$ sodium fluoride. Cells were sonicated for $10 \mathrm{sec}$ every $30 \mathrm{sec} 3$ times for 2 cycles. Following sonication, cell lysates were centrifuged at $13,362 \mathrm{x}$ g for $10 \mathrm{~min}$ at $4^{\circ} \mathrm{C}$ and then the supernatant was collected. Total proteins were quantified using a bicinchoninic acid protein assay (Sigma-Aldrich; Merck KGaA) following the manufacturer's instructions. For western blotting, $300 \mu \mathrm{g}$ MDA-MB-231 and $400 \mu \mathrm{g}$ MCF-7 proteins were resolved on $12 \%$ SDS-PAGE gels and subsequently transferred to polyvinylidene difluoride membranes. Non-specific binding proteins were blocked in $1 \%$ bovine serum albumin (BSA) (Cell Signaling Technology, Inc.) for $1 \mathrm{~h}$ at room temperature. After blocking, membranes were incubated with polyclonal rabbit antibodies against AQP1 (cat. no. bs-1506R), AQP3 (cat. no. bs-1253R) and AQP5 (cat. no. bs-1554R) (all 1:1,000; all BIOSS) in $1 \%$ BSA, and monoclonal mouse antibody against 
Table II. Volumes, cell densities and conditions used for RT-qPCR, immunocytochemistry and the cell viability assays.

\begin{tabular}{|c|c|c|c|c|c|}
\hline Method & Plate & $\begin{array}{c}\text { Cell } \\
\text { density/well }\end{array}$ & $\begin{array}{l}\text { Solution A: } \\
\text { siRNA }(\mu 1)\end{array}$ & $\begin{array}{c}\text { Solution B: } \\
\text { Lipofectamine }(\mu 1)\end{array}$ & $\begin{array}{l}\text { Reduced serum } \\
\text { media }(\mu 1)\end{array}$ \\
\hline RT-qPCR & 6-well & $2.0 \times 10^{5}$ & $\begin{array}{c}8.0+125.0 \mu 1 \\
\text { Opti-MEM }\end{array}$ & $\begin{array}{l}3.7+125.0 \\
\text { Opti-MEM }\end{array}$ & 750 \\
\hline Immunocytochemistry & 24-well & $2.5 \times 10^{5}$ & $\begin{array}{l}1.2+25.0 \mu 1 \\
\text { Opti-MEM }\end{array}$ & $\begin{array}{l}0.7+25.0 \mu 1 \\
\text { Opti-MEM }\end{array}$ & 250 \\
\hline Cell viability assay & 96-well & $1 \times 10^{4}$ & $\begin{array}{l}0.1+5.0 \mu 1 \\
\text { Opti-MEM }\end{array}$ & $\begin{array}{l}0.2+5.0 \mu 1 \\
\text { Opti-MEM }\end{array}$ & 80 \\
\hline
\end{tabular}

RT-q, reverse transcription-quantitative; si, small interfering.

$\beta$-actin $(1: 1,000$; cat. no. bsm-51011M; BIOSS) with shaking overnight at $4^{\circ} \mathrm{C}$. Subsequently, membranes were washed with $0.1 \%$ Tween-20 in Tris-buffered saline (TBTS) prior to and after the membranes were incubated in 5\% milk with $\mathrm{IgG}$ horseradish peroxidase-conjugated secondary antibodies (1:1,000; cat. nos. 7074 and 7076; Cell Signaling Technology, Inc.) for $1 \mathrm{~h}$ with shaking at room temperature. Protein bands were detected on the C-DiGit ${ }^{\circledR}$ Blot Scanner (LI-COR Biosciences) using SignalFire ${ }^{\mathrm{TM}}$ ECL reagent (Cell Signaling Technology, Inc.). Band intensities were quantified using ImageJ analysis software version 1.46r (National Institutes of Health) and normalized to loading control ( $\beta$-actin) band intensity in each lane.

Immunocytochemistry. MDA-MB-231 and MCF-7 cells $\left(3 \times 10^{5}\right)$ were grown on coverslips in 6-well plates and incubated for $48 \mathrm{~h}$ in a humidified atmosphere containing $5 \% \mathrm{CO}_{2}$ at $37^{\circ} \mathrm{C}$. After cryoinjury, cells were fixed with $4 \%$ paraformaldehyde overnight at $4^{\circ} \mathrm{C}$. Then, cells were washed with TBST 3 times, followed by permeabilization with $0.5 \%$ Triton-X-100 in TBST for $30 \mathrm{~min}$ at room temperature. Cells were then blocked with $1.5 \%$ goat serum (cat. no. ab7481; Abcam) in $1 \%$ BSA for $1 \mathrm{~h}$ at room temperature. Subsequently, cells were incubated overnight at $4{ }^{\circ} \mathrm{C}$ with rabbit monoclonal antibodies against AQP1 (1:200; cat. no. ab168387; Abcam) and AQP5 (1:200; cat. no. cab92320; Abcam), and a rabbit polyclonal against AQP3 (cat. no. ab125219; 1:200; Abcam). Then, cells were washed with TBST 3 times prior to and after incubation in the dark with a goat polyclonal Alexa Fluor ${ }^{\circledR} 488$ secondary antibody (1:200; cat. no. ab150077; Abcam) in 1\% BSA for $1 \mathrm{~h}$ at room temperature. Slides were then mounted using Fluoroshield $^{\mathrm{TM}}$ with DAPI (Sigma-Aldrich; Merck KGaA) and kept in the dark at $4^{\circ} \mathrm{C}$ before visualization at $\mathrm{x} 40$ magnification using a ZEISS LSM 710 confocal microscope (Zeiss AG).

Transfection of cells with small interfering (si)RNA. siRNAs against AQP1 (cat. no. sc-29711), AQP3 (cat. no. sc-29713) and AQP5 (cat. no. sc-29717; all from Santa Cruz Biotechnology, Inc.) consisting of 3 target-specific 19-25 nucleotides were used to knock down gene expression for $6 \mathrm{~h}$ in a humidified $5 \% \mathrm{CO}_{2}$ atmosphere at $37^{\circ} \mathrm{C}$. Control siRNA (cat. no. sc-37007; Santa Cruz Biotechnology, Inc.) consisting of a scrambled sequence was used as the negative control. MDA-MB-231 and MCF-7 cells were transfected with Lipofectamine ${ }^{\circledR} 3000$ (Invitrogen;
Thermo Fisher Scientific, Inc.) according to the manufacturer's protocols. The concentrations of siRNA, including the control siRNA, used for each transfection were: RT-qPCR, $10 \mu \mathrm{g} / \mathrm{ml}$; immunocytochemistry, $1.5 \mu \mathrm{g} / \mathrm{ml}$; and cell viability assay, $0.12 \mu \mathrm{g} / \mathrm{ml}$ (Table II). After $6 \mathrm{~h}$, the media was aspirated and fresh Advanced DMEM was added. After $48 \mathrm{~h}$, cells were cryoinjured for $10 \mathrm{~min}$ at $-13^{\circ} \mathrm{C}$ and processed the following day. The transfection efficiency was assessed by RT-qPCR as described above.

Cell viability assay. Cell viability was assessed using a Sulforhodamine B (SRB) assay (Sigma-Aldrich; Merck KGaA) as described by Skehan et al (55). Cells were seeded $\left(1 \times 10^{4}\right)$ in 96-well plates in triplicate for $24 \mathrm{~h}$ followed by transfection for $48 \mathrm{~h}$. At $24 \mathrm{~h}$ post cryoinjury, cells were fixed with $10 \%$ trichloroacetic acid (TCA) for $30 \mathrm{~min}$ at $4^{\circ} \mathrm{C}$. TCA was then aspirated and dried in a $37^{\circ} \mathrm{C}$ oven before the cells were stained with $0.4 \%$ SRB dissolved in $1 \%$ acetic acid for $10 \mathrm{~min}$ at room temperature. To remove the unbound dye, cells were washed with $1 \%$ acetic acid and then dried in a $37^{\circ} \mathrm{C}$ oven. The bound dye was then solubilized with $10 \mathrm{mM}$ Tris base solution $(\mathrm{pH} 10.5)$ and shaken before measuring the absorbance. Absorbance was measured at a wavelength of $540 \mathrm{~nm}$ with a reference wavelength of $650 \mathrm{~nm}$ using a microplate reader. Cell viability was calculated according to the following formula: Cell viability $=100-[($ absorbance of treated cells/absorbance of untreated cells) x100].

Statistical analysis. Data are presented as the mean \pm SD of at least 3 repeats. Means were compared using one-way ANOVA with the post hoc Tukey's test used for pairwise comparisons. All statistical tests were carried out using IBM SPSS Statistics v.25 (IBM Corp). Graphs were drawn using Microsoft Excel v.2002 (Microsoft Corporation). $\mathrm{P}<0.05$ was considered to indicate a statistically significant difference.

\section{Results}

Changes in mRNA expression levels of AQP1, AQP3 and AQP5 in breast cancer cells upon cryoinjury after 2, 6 and $24 \mathrm{~h}$. Breast cancer cells (MCF-7 and MDA-MB-231) were incubated at $-13,0$ and $37^{\circ} \mathrm{C}$ for $10 \mathrm{~min}$. A temperature of $0^{\circ} \mathrm{C}$ was chosen as the control for non-freezing condition, while $-13^{\circ} \mathrm{C}$ was the lowest temperature capable of achieving freezing 


\section{MDA-MB-231}
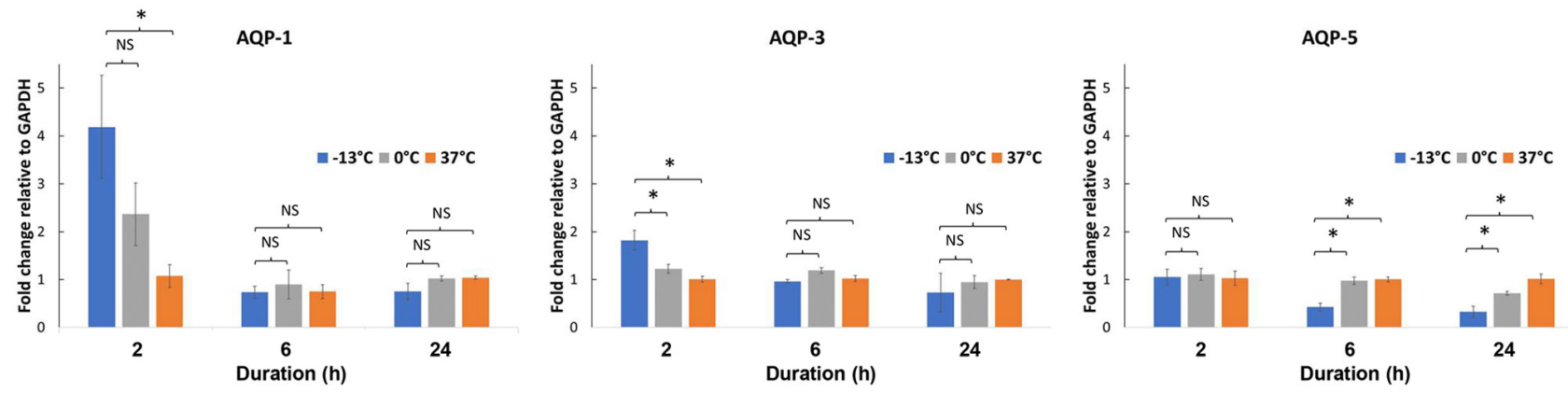

MCF-7
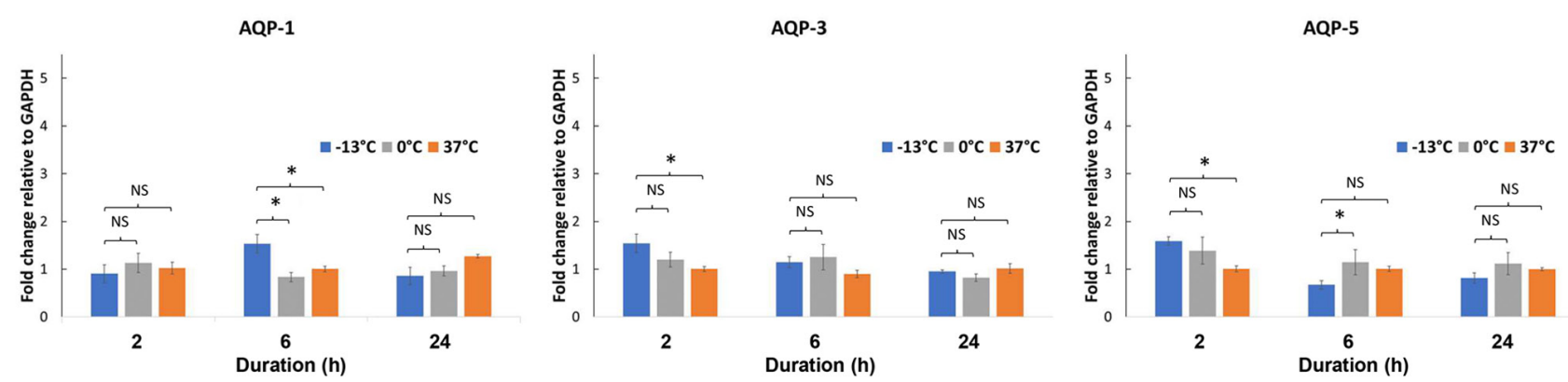

Figure 1. Aquaporin gene expression in response to temperature exposure at $-13,0$ and $37^{\circ} \mathrm{C}$ in 2 breast cancer cell lines (MDA-MB-231 and $\mathrm{MCF}-7$ ). Following temperature exposure cells were incubated at $37^{\circ} \mathrm{C}$ for 2,6 and $24 \mathrm{~h}$. Expression levels of AQP1, AQP3 and AQP5 were then analyzed after 2-, 6- and 24-h periods. ${ }^{*} \mathrm{P}<0.05$. AQP, aquaporin.

whilst maintaining cell viability. Following this, AQP1, AQP3 and AQP5 mRNA expression levels were analyzed at 2,6 and $24 \mathrm{~h}$ of incubation. Several different time points were used as the rate of gene expression varies depending on the gene. With the exception of AQP1 expression in MDA-MD-231 cells $(\mathrm{P}<0.05)$, no significant fold-change in AQP expression was observed in the MCF-7 and MDA-MB-231 upon treatment at different temperatures or incubation times (Fig. 1). A 4-fold increase in the AQP1 gene expression was observed in MDA-MB-231 cells, $2 \mathrm{~h}$ following freezing at $-13^{\circ} \mathrm{C}(\mathrm{P}<0.05)$, while a 2 -fold increase was seen at $0^{\circ} \mathrm{C}$ when compared with control cells kept at $37^{\circ} \mathrm{C}$ (Fig. 1).

Changes in AQP1, AQP3 and AQP5 protein expression levels in breast cancer cells upon cryoinjury as determined via western blotting. AQP1, AQP3 and AQP5 protein expression levels in MCF-7 and MDA-MB-231 cells were quantified following exposure to frozen $\left(-13^{\circ} \mathrm{C}\right)$ and non-frozen $\left(37^{\circ} \mathrm{C}\right)$ temperatures (Fig. 2). No clear difference in AQP-3 protein content was observed for either cell line at the two temperatures (Fig. 2A and B). Following exposure to freezing temperature, AQP-1 protein content was increased in both cell lines by 7 - and 3-fold in MDA-MB-231 $(\mathrm{P}<0.001)$ and MCF-7 $(\mathrm{P}<0.05)$ cells, respectively, when compared with non-frozen cells maintained at $37^{\circ} \mathrm{C}$ (Fig. 2B). AQP5 protein content was increased by 20 -fold $(\mathrm{P}<0.001)$ following exposure to freezing temperature only in MCF-7 cells (Fig. 2B).

Localization of AQP1 AQP3 and AQP5 in breast cancer cells. The intracellular localization of AQP proteins in both cell lines was determined by immunocytochemistry. The exposure to freezing temperature altered the localization of AQPs in MDA-MB-231 cells (Fig. 3A), but not in MCF-7 cells (Fig. 3B), when compared with non-frozen cells maintained at $37^{\circ} \mathrm{C}$. With regards to MDA-MB-231 cells, a strong AQP1 staining was observed within the cytosol in non-frozen cells and within the plasma and nuclear membranes in frozen cells (Fig. 3A). However the staining was more intense in the nuclear membrane when compared with the plasma membrane in MDA-MB-231 cells exposed to freezing. Similar staining for AQP3 expression was observed in the plasma membrane following freezing of MDA-MB-231 cells (Fig. 3A). Whereas AQP5 protein expression was clustered and localized in the nucleus in both treatment conditions (Fig. 3A). No observable difference in intensity was seen between the plasma and nuclear membranes for AQP3 and AQP5 staining in MDA-MB-231 cells when compared to non-frozen cells (Fig. 3A). In MCF-7 cells, staining for AQP1 demonstrated that the freezing temperature affected the protein localization (Fig. 3B). AQP1 had a diffused cytoplasm staining and accumulated in the plasma membrane when compared with AQP1 localization in non-frozen cells (Fig. 3B). Few cells had an intense nuclear staining as presented by the arrows (Fig. 3B). AQP3 proteins formed small clusters localized at the plasma membrane in MCF-7 cells exposed to the freezing temperature when compared to non-frozen cells maintained at $37^{\circ} \mathrm{C}$. (Fig. 3B). The staining of AQP5 in MCF-7 cells revealed a similar clustering pattern observed previously in MDA-MB-231 cells (Fig. 3A) and was not affected by the freezing temperature (Fig. 3B). However, the plasma membrane localization was more intense following exposure to freezing temperature as presented by the arrows (Fig. 3A and B). 
A

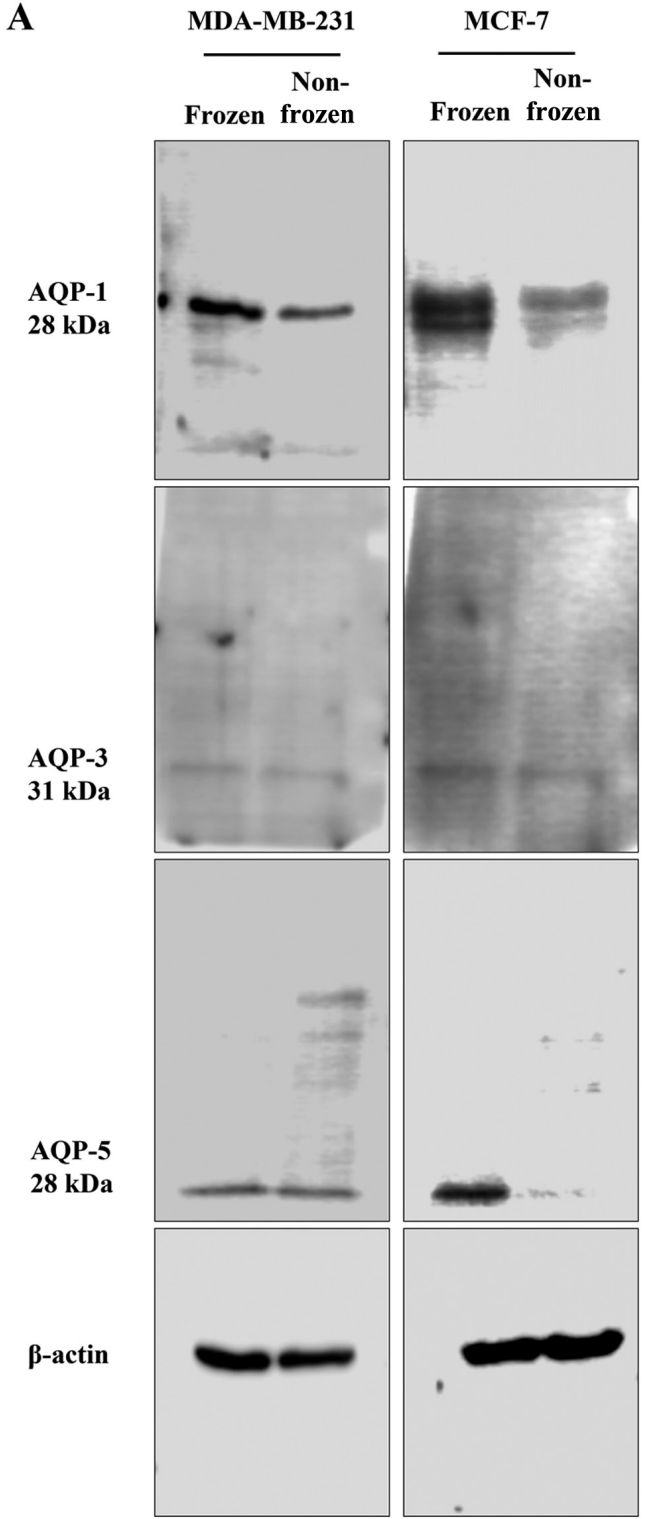

B
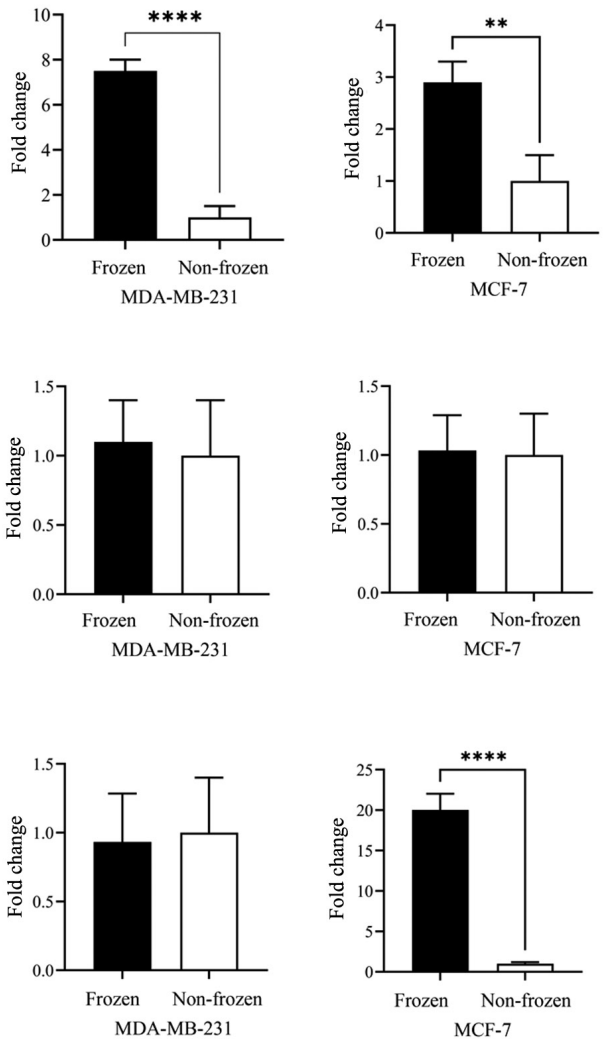

Figure 2. Effect of the exposure of breast cancer cells to frozen $\left(-13^{\circ} \mathrm{C}\right)$ and non-frozen $\left(37^{\circ} \mathrm{C}\right)$ temperatures on the expression of $\mathrm{AQPs} 1,3$ and $5 .(\mathrm{A})$ Total cell lysates were analyzed by western blotting using AQP-1, 3, and 5 antibodies and $\beta$-actin as a loading control. (B) Quantification of the AQP-1, 3, and 5 normalized to $\beta$-actin and expressed as fold of change. ${ }^{* *} \mathrm{P}<0.05$ and ${ }^{* * * *} \mathrm{P}<0.001$. AQP, aquaporin.

Assessment of gene knockdown following siRNA transfection. AQP gene silencing was assessed via RT-qPCR. A successful knockdown was achieved after $48 \mathrm{~h}$ of transfection, with an efficiency of $90 \%$. The expression of AQP genes was normalized to GAPDH and compared with control cells maintained at $37^{\circ} \mathrm{C}$. MDA-MB-231 cells demonstrated a reduction in gene expression for all 3 types of aquaporin siRNA transfected in both non-frozen cells $(\mathrm{P}<0.05)$ maintained at $37^{\circ} \mathrm{C}$ and frozen cells $(\mathrm{P}<0.05$ for $\mathrm{AQP} 1$ and $\mathrm{AQP} 3)$ exposed to $-13^{\circ} \mathrm{C}$ (Fig. 4). Similar reductions in gene expression were observed in $\mathrm{MCF}-7$ cells $(\mathrm{P}<0.05$ for AQP3 and AQP5; both frozen and non-frozen exposures). However, this was not the case for AQP1 whose expression was increased following transfection of AQP1 siRNA (Fig. 4).

Assessment of cell viability following siRNA transfection and exposure to freezing in breast cancer cells. Following transfection with AQP-specific or control siRNA, cells were either exposed to freezing temperature or not. Cell viability was then assessed using the SRB assay and comparisons were made between non-frozen and frozen cells. The percentage change in cell viability for each AQP-specific siRNA group was calculated by normalizing the cell viability in the transfected cells to the cell viability in the cells transfected with scramble control siRNA. These were then represented as percentage differences. The exposure of both MCF-7 and MDA-MB-231 cells to freezing temperature did not affect their viability when transfected with the scrambled siRNA.

With regards to MDA-MD-231 cells, there was a significant decrease in cell viability for frozen cells transfected with AQP1, AQP3 and AQP5 siRNA compared with the non-frozen cells $(\mathrm{P}<0.05$; Fig. 5A). This reduction in cell viability was $32.6,46.4$ and $32.0 \%$ for AQP1, AQP3 and AQP5 siRNA transfected cells, respectively (Fig. 5A). There was a similarly significant reduction in the cell viability of MCF-7 cells that were frozen compared with non-frozen 
A
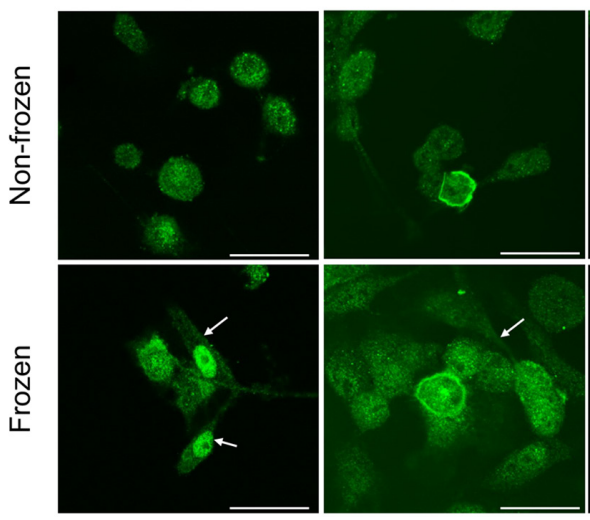

B
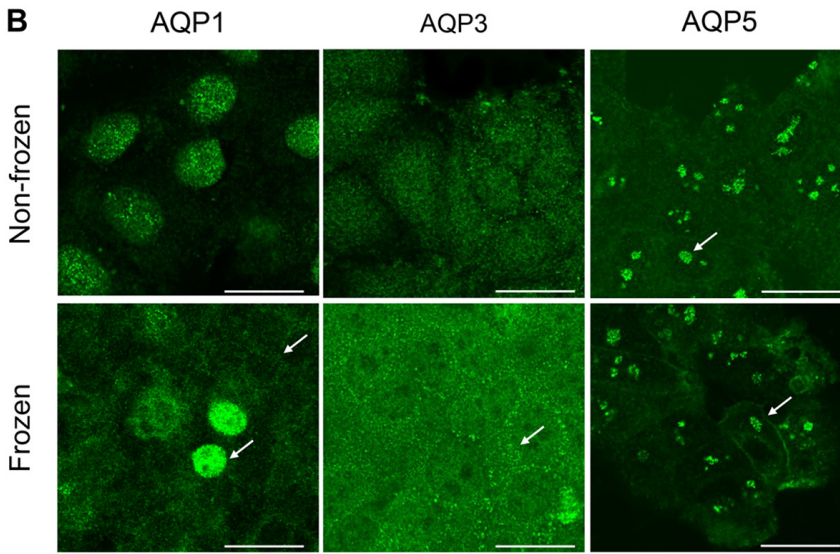

Figure 3. Representative results of immunocytochemistry of aquaporin proteins (AQP1, AQP3 and AQP5) in (A) MDA-MB-231 and (B) MCF-7 cells Upper panels show cells not exposed to freezing temperatures while lower panels show cells that were frozen at $-13^{\circ} \mathrm{C}$. (A) Intense staining of AQP1 and AQP3 was seen within the plasma and nuclear membranes following freezing for MDA-MB-231 cells (Fig. 3A, arrows); indicating relocation of AQP1 and AQP3 to membranes. Similar staining for AQP3 expression was observed in the plasma membrane following the freezing of MDA-MB-231 cells (Fig. 3A, arrows). AQP5 protein expression was clustered and localized in the nucleus in both treatment conditions (Fig. 3A, arrows). (B) In MCF-7 cells AQP1 and AQP3 showed localization in membranes following freezing. AQP1 had a diffused cytoplasm staining and accumulated in the plasma membrane compared with AQP1 localization in non-frozen cells (Fig. 3B, arrows); few cells had intense nuclear staining (Fig. 3B, arrows). Plasma membrane localization of AQP5 in MCF-7 cells appeared more intense following exposure to freezing temperature (Fig. 3B, arrows). There were no discernible changes in staining and localization of AQP5 in both MDA-MB-231 and MCF-7 cells in response to freezing. Scale bar, $25 \mu \mathrm{m}$. AQP, aquaporin.

cells, for cells transfected with siRNA targeting AQP3 and AQP5 only $(\mathrm{P}<0.05$; Fig. 5B). There was no statistical difference between MCF-7 cells transfected with siRNA against AQP1, which was the one transfection that failed to silence the test-gene under investigation (Fig. 5B). The reductions observed in cell viability were $15.5,15.7$ and $40.8 \%$ for AQP1, AQP3 and AQP5 siRNA transfected cells, respectively (Fig. 5B).

\section{Discussion}

In the present study, cryoinjury did not have a major influence on gene expression of AQPs in breast cancer cells. Based upon RT-qPCR results, the freezing of cells induced an increase in the gene expression of AQP1 only in the MDA-MD-231 cell line. In contrast in the present study, freezing did not appear to have a major effect on the expression of AQP3 and AQP5 in MDA-MB-231 cells or on AQP-1, 3 and 5 in MCF-7 cells. In addition to mRNA-based gene expression, AQP protein levels were also assessed as part of the present study. Bands of immunoreactivity were present on western blots, which indicated that freezing cells had no major influence on the expression of AQP3 protein. However, the AQP1 protein expression was sensitive to the variation of temperature in both cell lines as observed by the increase band intensity following the exposure to freezing temperature when compared with control cells maintained at $37^{\circ} \mathrm{C}$. The expression of AQP5 was sensitive to the exposure of freezing temperature only in MCF-7, but not in MDA-MB-231 cells. This finding of the present study demonstrated the heterogeneity of breast cancers. The use of an additional quantitative assay to investigate the expression of this protein may further elucidate the effect of freezing on protein expression in these cell lines. In the present study, the measure of the presence or absence of AQP protein does not give an indication of the cellular location of the detected AQP protein immunoreactivity. Hence, these results should be evaluated in tandem with the immunocytochemistry images. Immunofluorescence staining in the present study demonstrated that freezing cells had the effect of translocating aquaporins from the cytosol to the plasma membrane and incorporating these protein channels in the cell membranes. This redistribution observed in the present study, may reflect the involvement of aquaporin in the movement of intercellular water associated with freezing. Results from the cell lines in the present study suggested that freezing did not only influence the amount of AQP protein expression in the cell, but also influenced the cellular localization of these proteins.

Cryoablation is considered an efficacious breast cancer treatment and this efficacy is due to the destructive effects of cold temperatures on the cellular ultrastructure of tumor tissue (5). The destruction of neoplastic tissue is achieved though freeze/thaw cycles using a cryoprobe (12). The goal of the present study was to assess cryo-damage in association with aquaporin downregulation using breast cancer cells in vitro. Clinically, the first freeze cycle in cryoablation has a duration of 5-13 min (56,57). Hence, a freezing time of $10 \mathrm{~min}$ in the in vitro setting in the present study was considered appropriate. The time taken for the temperature to decrease from $37^{\circ} \mathrm{C}$ to below $0^{\circ} \mathrm{C}$ was $5 \mathrm{~min}$ and the actual freezing time of the cells at $-13^{\circ} \mathrm{C}$ was $5 \mathrm{~min}$ in the present study. In the present study, 10 min was the time needed for the media to freeze whilst still preserving the integrity of the cells. The present study replicated elements of the in vivo clinical application of cryoinjury. However, this study could not mimic or simulate the in vivo environment. The freezing protocols employed clinically use temperatures below $-40^{\circ} \mathrm{C}$ and consist of freeze/thaw cycles as freezing alone once does not uniformly damage the targeted tumor (12). Multiple freezing cycles extend the zone of destruction ensuring maximum lethality (17). However, on the margins of the targeted area, the cells are exposed to subzero temperatures where survival of the cancer cells is possible.

Cells that express AQPs acquire a tolerance to freezing by evading cell membrane damage (33). It was previously reported that AQP3 gene silencing increased cryosensitization 


\section{MDA-MB-231}

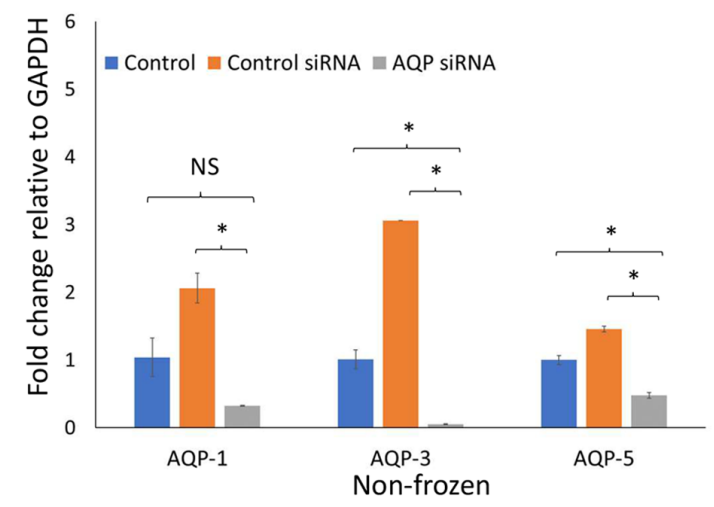

\section{MCF-7}

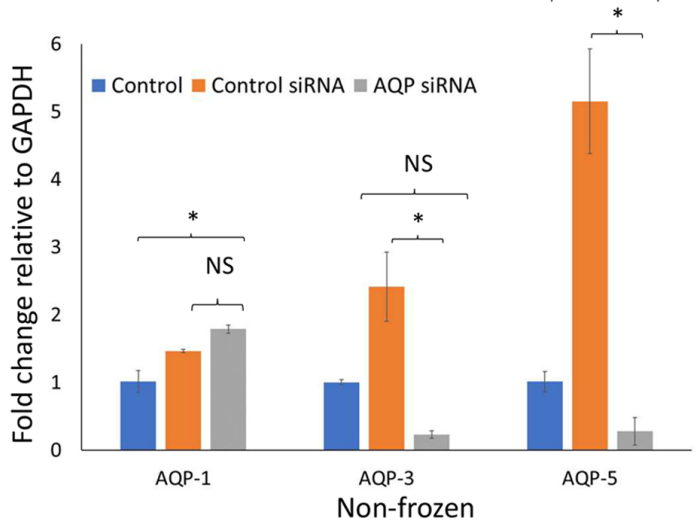

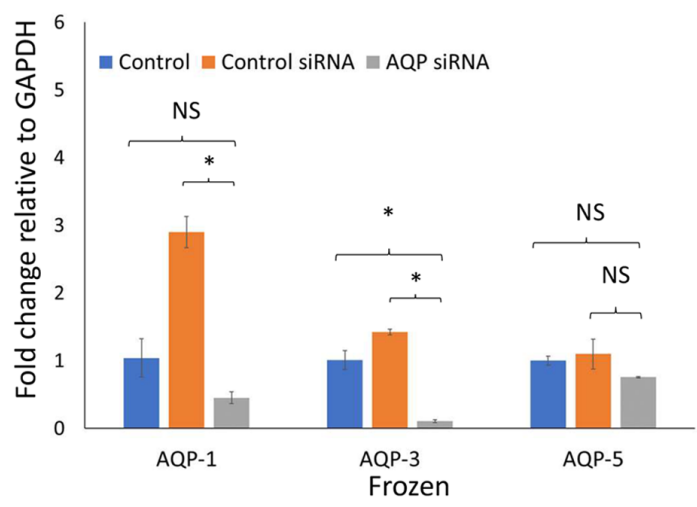

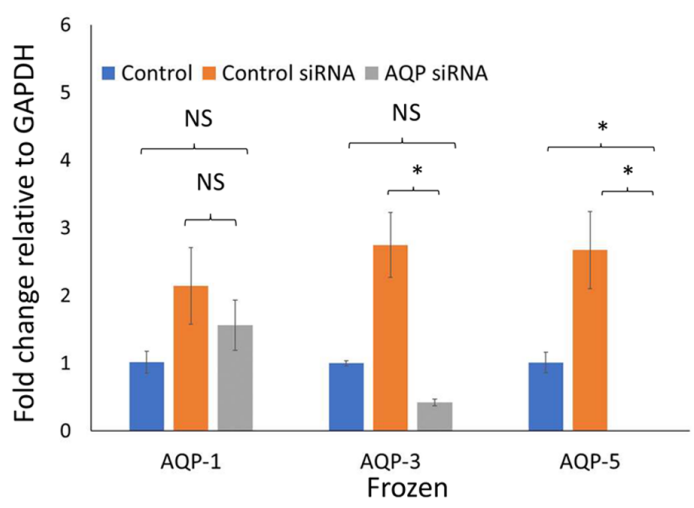

Figure 4. Assessment of gene knockdown following small siRNA transfection. AQP gene silencing was assessed using RT-qPCR in MDA-MB-231 and MCF-7 breast cancer cells exposed to frozen and non-frozen conditions. siRNA targeting AQP1, AQP3 and AQP5 were used to knock down gene expression. In addition, untreated cells were used as a control as well as control-siRNA. Following transfection of cells with siRNA, cells were cryoinjured for $10 \mathrm{~min}$ at $-13^{\circ} \mathrm{C}$. Gene expression was then assessed by RT-qPCR relative to the housekeeping gene GAPDH. ${ }^{*} \mathrm{P}<0.05$, Si, small interfering; RT-q, reverse transcription-quantitative; $\mathrm{AQP}$, aquaporin.
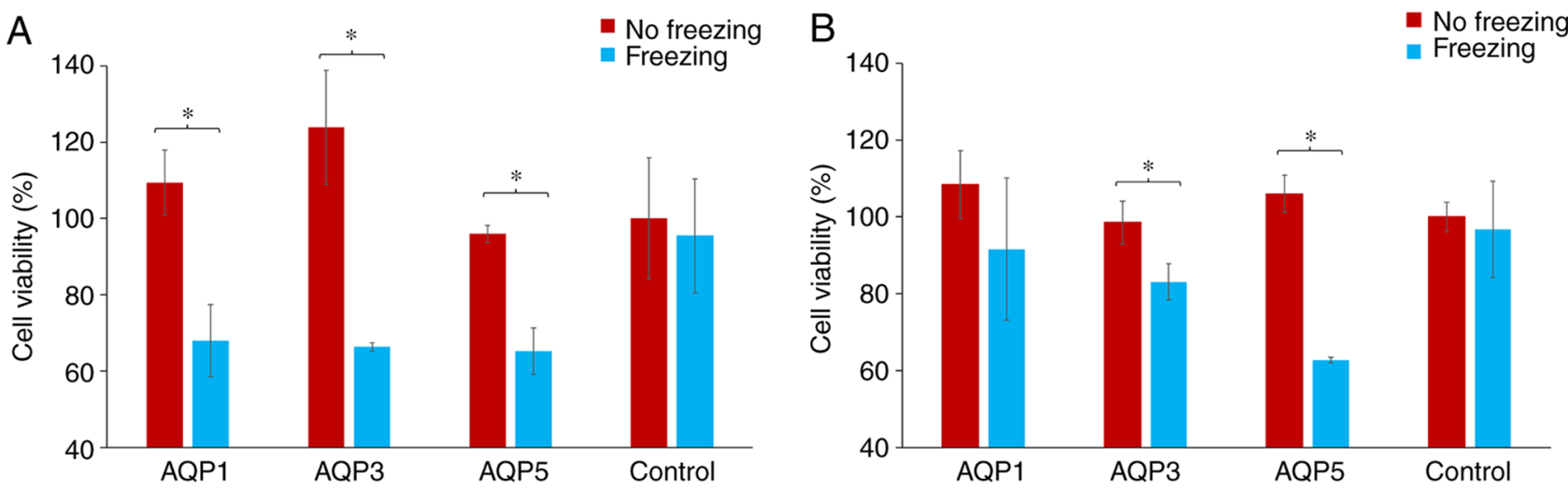

Figure 5. Assessment of cell viability following siRNA transfection and exposure to freezing in MDA-MB-231 and MCF-7 breast cancer cells. (A) MDA-MB-231 and (B) MCF-7 cells. Cell viability was assayed using the Sulforhodamine B assay following transfection with siRNA and exposure to freezing and non-freezing conditions. Cells were transfected with siRNA targeting 3 aquaporins: AQP1, AQP3 and AQP5. The control group was the scrambled negative-control siRNA. ${ }^{*} \mathrm{P}<0.05$. Si, small interfering; AQP, aquaporin.

in prostate cancer cells and that freezing caused the relocation of AQP3 from the cytosol to the membrane (22). To the best of our knowledge, the present study is the first to report similar cellular responses to freezing in breast cancer cell lines. Fujita et al (58) previously found that enhanced expression of AQP3 in cancer cells was an attempt to overcome osmotic stress. An upregulation on exposure to mild hypothermia was reported in earlier studies $(58,59)$. It has also been demonstrated that cryoinjury leads to increased expression of AQP3 in prostate cancer cells (22). However, an increase in AQP3 expression was not observed in the 2 breast cancer cell lines used in the present study, 
as determined using RT-qPCR and immunocytochemistry. A cellular redistribution of AQPs was observed following freezing at $-13^{\circ} \mathrm{C}$ with MDA-MB-231 cells, but not with MCF-7 cells. This difference in localization between the 2 cell lines may be related to differences in growth patterns between the two. Temperatures lower than $-13^{\circ} \mathrm{C}$ may have brought about a similar effect with MCF-7 as was observed with MDA-MB-231 cells. However, the low temperatures of $-30^{\circ} \mathrm{C}$ or $-40^{\circ} \mathrm{C}$ that are typically used clinically would likely destroy cells and alter the fluidity of the proteins within them (17). Temperatures of $\sim-40 \mathrm{C}$ cause both intra- and extra-cellular water to solidify (17). Hence, a temperature of $-13^{\circ} \mathrm{C}$ was chosen in the present study to mimic the behavior of cancer cells located near the zone targeted by the ultra-cold temperatures administered during clinical cryotherapy procedures. Clinically, temperatures located on the margins of the cryo-ablated area, such as $-13^{\circ} \mathrm{C}$, will recover $(12,22)$. This damage to cells may be influenced by the expression of aquaporins $(12,22)$.

AQP expression is associated with numerous pathologies, which includes tumor metastasis $(34,60,61)$. However, there are currently no definitive, small molecule AQP inhibitors available for therapeutic use (62). Heavy metal compounds, such as mercury, are effective AQP inhibitors (22), but in the present study they were considered inappropriate for use in a biological experiment due to their non-specificity and toxicity. Hence, the present study employed a gene-silencing technique to investigate the role of AQPs in cryosensitization. In the present study, the transfection of breast cancer cells with siRNA had an influence on cell viability following cryodamage. The viability of frozen MDA-MD-231 cells was decreased in the present study following transfection with AQP1, AQP3 and AQP5 siRNA when compared with MDA-MB-231 cells transfected with siRNA-NC. A similar reduction in cell viability was observed in the present study with MCF-7 cells transfected with AQP3 siRNA, which was more pronounced with AQP5 siRNA. In the present study, the transfection of AQP1 siRNA in MCF-7 cells led to an increase in AQP1 mRNA expression probably due to the siRNA failing to target AQP1 mRNA efficiently in MCF-7 cells. The aforementioned findings of the present study suggested that the silencing of AQP genes exacerbated cell damage associated with freezing. Notably the expression levels of some aquaporins were significantly higher in the control siRNA groups as compared to those in the untransfected control groups. The process of transfection may have had an impact on the aquaporin expression which in turn resulted in the increase expression of aquaporin in the present study as transfection effects the permeability of cells (63).

It has been demonstrated that AQP1 is upregulated in breast cancer cells, which is associated with poor patient prognosis resulting from the induction of angiogenesis which leads to metastasis (64). It is speculated that AQP1 upregulation is stimulated by estrogen acting via the ER (34). MDA-MB-231 cells are lacking in these receptors (65). However, freezing these ER-deficient cells in the present study increased AQP1 expression. This implied that the underlying mechanism of induction was independent of ER. In addition, an increase in the expression of AQP1 was not observed in the MCF-7 cells in the present study, which do possess an ER (65).

Previous studies have demonstrated AQP1 to be upregulated in breast cancer cells and this has been associated with enhanced cell proliferation and invasion, which may make AQP1 a potential prognostic marker for breast cancer $(38,66)$. The increase of AQP1 in MDA-MB-231 following freezing that was observed in the present study may promote the cell's tolerance to cryo-damage as the knockdown of AQP1 expression decreased MDA-MB-231 cell viability. It is therefore reasonable to assume that increase expression of AQP1 allows the cells to recover from cryoinjury. The techniques employed in the current study measured quantitative fold-changes in RNA and the presence or absence of aquaporin proteins. However, no measurement of aquaporin channel function activity was assessed. A functional assay of channel activity would add value to this investigation as cryoinjury and sensitization to injury are active processes (17). These processes depend upon the activity of the channels studied rather than the mere absences, presences or location of the protein $(34,61,64)$. It has been demonstrated that AQP1 activity is regulated by cyclic nucleotides, such as cAMP and protein kinase pathways, such as focal adhesion kinase (64). Post-translational modifications, such as phosphorylation regulate AQP1 activity (67). The methods adopted in the current study did not consider such necessary modifications to aquaporin proteins.

Clinically, multiple freeze-thaw cycles are crucial to the therapeutic application cry-injury (17). However, the laboratory experimental setting employed in the present study did not allow for multiple freezing. This is a limitation of the laboratory approach to investigating cryoinjury using cell culture. The limitations of the present study also included the use of a cell monolayer instead of tissue. In addition, the in vitro system did not incorporate estrogen exposure as part of the experimental design. Future studies should examine the relationship between estrogen and AQP1 in this ER-expressing cell line in the context of cryodamage.

In summary, in the present study, freezing breast cancer cells induced the redistribution of AQP proteins from the cytosol to the cell membrane. Inhibition of AQP function exacerbated cell damage associated with freezing. This indicated that reduced aquaporin function may be used as an adjunct to cryotherapy. The combination of cryotherapy and AQP inhibition may result in less aggressive freezing protocols whilst achieving more complete ablation of tumors and, ultimately, lower treatment failure for patients with breast cancer.

\section{Acknowledgements}

The authors would like to thank Mrs. Asma Mostafa (Sharjah Institute of Research and Technology, University of Sharjah ) and Dr Nabil El Zein (Faculty of Science, Lebanese University) for their technical help, advice and assistance regarding the breast cancer cell lines.

\section{Funding}

This study was supported by a RCSI (Bahrain) internal research grant (no. BR00070). 


\section{Availability of data and materials}

The datasets used and/or analyzed during the current study are available from the corresponding author on reasonable request.

\section{Authors' contributions}

HA performed the cell and molecular laboratory experiments, data analysis and wrote the manuscript. FM was involved data conception and analysis. SeT conceived the experimental design, conducted data analysis and revised the manuscript for important intellectual content. KG performed the data analysis of the laboratory work. SaT performed and supervised laboratory work. SF was involved in data collection and analysis and drafted the initial manuscript. HA, SeT, FM, and SF confirmed the authenticity of all the raw data. All the authors have read and approved the manuscript.

\section{Ethics approval and consent to participate}

Not applicable.

\section{Patient consent for publication}

Not applicable.

\section{Competing interests}

The authors declare that they have no competing interests.

\section{References}

1. Bray F, Ferlay J, Soerjomataram I, Siegel RL, Torre LA and Jemal A: Global cancer statistics 2018: GLOBOCAN estimates of incidence and mortality worldwide for 36 cancers in 185 countries. CA Cancer J Clin 68: 394-424, 2018.

2. Global Burden of Disease Cancer Collaboration, Fitzmaurice C, Allen C, Barber RM, Barregard L, Bhutta ZA, Brenner H, Dicker DJ, Chimed-Orchir O, Dandona R, et al: Global, regional, and national cancer incidence, mortality, years of life lost, years lived with disability, and disability-adjusted life-years for 32 cancer groups, 1990 to 2015: A systematic analysis for the global burden of disease study. JAMA Oncol 3: 524-548, 2017.

3. PDQ Adult Treatment Editorial Board: Breast cancer treatment (Adult) $\left(\mathrm{PDQ}^{\circledR}\right)$ : Patient version. In: PDQ Cancer Information Summaries. National Cancer Institute (USA), Bethesda, MD, 2002.

4. Sharma GN, Dave R, Sanadya J, Sharma P and Sharma KK: Various types and management of breast cancer: An overview. J Adv Pharm Technol Res 1: 109-126, 2010.

5. Pusceddu C, Melis L, Ballicu N, Meloni P, Sanna V, Porcu A and Fancellu A: Cryoablation of primary breast cancer in patients with metastatic disease: Considerations arising from a single-centre data analysis. Biomed Res Int 2017: 3839012, 2017.

6. Erinjeri JP and Clark TW: Cryoablation: Mechanism of action and devices. J Vasc Interv Radiol 21 (Suppl 8): S187-S191, 2010.

7. Pusceddu C,Paliogiannis P, Nigri G and Fancellu A: Cryoablation in the management of breast cancer: Evidence to date. Breast Cancer (Dove Med Press) 11: 283-292, 2019.

8. Beji H, Pilleul F, Picard R, Tredan O, Bouhamama A, Peix M, Mavrovi E and Mastier C: Percutaneous cryoablation of breast tumours in patients with stable metastatic breast cancer: Safety, feasibility and efficacy. Br J Radiol 91: 20170500, 2018.

9. Holmes DR: Breast cancer care during a pandemic: An opportune time for cryoablation? Breast Cancer Res Treat 182: 515-521, 2020.

10. Mahnken AH, König AM and Figiel JH: Current technique and application of percutaneous cryotherapy. Rofo 190: 836-846, 2018 (In English, German)
11. Niu L, Mu F, Zhang C, Li Y, Liu W, Jiang F, Li L, Liu C, Zeng J, Yao F, et al: Cryotherapy protocols for metastatic breast cancer after failure of radical surgery. Cryobiology 67: 17-22, 2013.

12. Baust JG, Gage AA, Bjerklund Johansen TE and Baust JM: Mechanisms of cryoablation: Clinical consequences on malignant tumors. Cryobiology 68: 1-11, 2014.

13. Aarts BM, Klompenhouwer EG, Rice SL, Imani F, Baetens T, Bex A, Horenblas S, Kok M, Haanen JBAG, Beets-Tan RGH and Gómez FM: Cryoablation and immunotherapy: An overview of evidence on its synergy. Insights Imaging 10: 53, 2019.

14. Gage AA and Baust J: Mechanisms of tissue injury in cryosurgery. Cryobiology 37: 171-186, 1998.

15. Hoffmann NE and Bischof JC: The cryobiology of cryosurgical injury. Urology 60 (Suppl 1): S40-S49, 2002.

16. Santucci KL, Snyder KK, Baust JM, Van Buskirk RG, Mouraviev V, Polascik TJ, Gage AA and Baust JG: Use of 1,25a dihydroxyvitamin D3 as a cryosensitizing agent in a murine prostate cancer model. Prostate Cancer Prostatic Dis 14: 97-104, 2011.

17. Baust JG, Snyder KK, Santucci KL, Robilotto AT, Van Buskirk RG and Baust JM: Cryoablation: Physical and molecular basis with putative immunological consequences. Int J Hyperthermia 36 (Suppl 1): S10-S16, 2019.

18. Clarke DM, Baust JM, Van Buskirk RG and Baust JG: Chemo-cryo combination therapy: An adjunctive model for the treatment of prostate cancer. Cryobiology 42: 274-285, 2001.

19. Clarke DM, Baust JM, Van Buskirk RG and Baust JG: Addition of anticancer agents enhances freezing-induced prostate cancer cell death: Implications of mitochondrial involvement. Cryobiology 49: 45-61, 2004.

20. Le Pivert P, Haddad RS, Aller A, Titus K, Doulat J, Renard M and Morrison DR: Ultrasound guided combined cryoablation and microencapsulated 5-Fluorouracil inhibits growth of human prostate tumors in xenogenic mouse model assessed by luminescence imaging. Technol Cancer Res Treat 3: 135-142, 2004.

21. Baust JM, Klossner DP, Robilotto A, Vanbuskirk RG, Gage AA, Mouraviev V, Polascik TJ and Baust JG: Vitamin D(3) cryosensitization increases prostate cancer susceptibility to cryoablation via mitochondrial-mediated apoptosis and necrosis. BJU Int 109: 949-958, 2012.

22. Ismail M, Bokaee S, Morgan R, Davies J, Harrington KJ and Pandha H: Inhibition of the aquaporin 3 water channel increases the sensitivity of prostate cancer cells to cryotherapy. Br J Cancer 100: 1889-1895, 2009.

23. Khajah MA and Luqmani YA: Role of aquaporins in breast cancer progression and metastasis. Tumor Met: 59-83, 2016.

24. Wang L, Zhang Y, Wu X and Yu G: Aquaporins: New targets for cancer therapy. Technol Cancer Res Treat 15: 821-828, 2016.

25. Hagedorn M, Lance SL, Fonseca DM, Kleinhans FW, Artimov D, Fleischer R, Hoque AT, Hamilton MB and Pukazhenthi BS: Altering fish embryos with aquaporin-3: An essential step toward successful cryopreservation. Biol Reprod 67: 961-966, 2002.

26. Edashige K, Yamaji Y, Kleinhans FW and Kasai M: Artificial expression of aquaporin-3 improves the survival of mouse oocytes after cryopreservation. Biol Reprod 68: 87-94, 2003.

27. Tanghe A, Van Dijck P, Colavizza D and Thevelein JM: Aquaporin-mediated improvement of freeze tolerance of Saccharomyces cerevisiae is restricted to rapid freezing conditions. Appl Environ Microbiol 70: 3377-3382, 2004.

28. Tanghe A, Van Dijck P and Thevelein JM: Why do microorganisms have aquaporins? Trends Microbiol 14: 78-85, 2006.

29. Tietz PS, McNiven MA, Splinter PL, Huang BQ and Larusso NF: Cytoskeletal and motor proteins facilitate trafficking of AQP1-containing vesicles in cholangiocytes. Biol Cell 98: 43-52, 2006.

30. Riethmüller C, Oberleithner H, Wilhelmi M, Franz J, Schlatter E, Klokkers J and Edemir B: Translocation of aquaporin-containing vesicles to the plasma membrane is facilitated by actomyosin relaxation. Biophys J 94: 671-678, 2008.

31. Conner AC, Bill RM and Conner MT: An emerging consensus on aquaporin translocation as a regulatory mechanism. Mol Membr Biol 30: 1-12, 2013.

32. Cohen E: Roles of aquaporins in osmoregulation, desiccation and cold hardiness in insects. Entomol Ornithol Herpetol S1: 1-17, 2012.

33. Kato Y, Miyauchi T, Abe Y, Kojić D, Tanaka M, Chikazawa N, Nakatake Y,Ko SB, Kobayashi D, Hazama A, et al: Unprecedented cell-selection using ultra-quick freezing combined with aquaporin expression. PLoS One 9: e87644, 2014. 
34. Wang J, Feng L, Zhu Z, Zheng M, Wang D, Chen Z and Sun H: Aquaporins as diagnostic and therapeutic targets in cancer: How far we are? J Transl Med 13: 96, 2015

35. Satooka H and Hara-Chikuma M: Aquaporin-3 controls breast cancer cell migration by regulating hydrogen peroxide transport and its downstream cell signaling. Mol Cell Biol 36: 1206-1218, 2016.

36. Zhu Z, Jiao L, Li T, Wang H, Wei W and Qian H: Expression of AQP3 and AQP5 as a prognostic marker in triple-negative breast cancer. Oncol Lett 16: 2661-2667, 2018.

37. Otterbach F, Callies R, Adamzik M, Kimmig R, Siffert W, Schmid KW and Bankfalvi A: Aquaporin 1 (AQP1) expression is a novel characteristic feature of a particularly aggressive subgroup of basal-like breast carcinomas. Breast Cancer Res Treat 120: 67-76, 2010.

38. Qin F, Zhang H, Shao Y, Liu X, Yang L, Huang Y, Fu L, Gu F and Ma Y: Expression of aquaporin1, a water channel protein in cytoplasm is negatively correlated with prognosis of breast cancer patients. Oncotarget 7: 8143-8154, 2016

39. Nielsen TO, Hsu FD, Jensen K, Cheang M, Karaca G, Hu Z, Hernandez-Boussard T, Livasy C, Cowan D, Dressler L, et al: Immunohistochemical and clinical characterization of the basal-like subtype of invasive breast carcinoma. Clin Cancer Res 10: 5367-5374, 2004

40. Hugh J, Hanson J, Cheang MC, Nielsen TO, Perou CM, Dumontet C, Reed J, Krajewska M, Treilleux I, Rupin M, et al: Breast cancer subtypes and response to docetaxel in node-positive breast cancer: Use of an immunohistochemical definition in the BCIRG 001 trial. J Clin Oncol 27: 1168-1176, 2009.

41. Blows FM, Driver KE, Schmidt MK, Broeks A, van Leeuwen FE, Wesseling J, Cheang MC, Gelmon K, Nielsen TO, Blomqvist $\mathrm{C}$, et al: Subtyping of breast cancer by immunohistochemistry to investigate a relationship between subtype and short and long term survival: A collaborative analysis of data for 10,159 cases from 12 studies. PLoS Med 7: e1000279, 2010

42. Carey LA, Dees EC, Sawyer L, Gatti L, Moore DT, Collichio F, Ollila DW, Sartor CI, Graham ML and Perou CM: The triple negative paradox: Primary tumor chemosensitivity of breast cancer subtypes. Clin Cancer Res 13: 2329-2334, 2007.

43. Dent R, Trudeau M, Pritchard KI, Hanna WM, Kahn HK Sawka CA, Lickley LA, Rawlinson E, Sun P and Narod SA: Triple-negative breast cancer: Clinical features and patterns of recurrence. Clin Cancer Res 13: 4429-4434, 2007.

44. Liedtke C, Mazouni C, Hess KR, André F, Tordai A, Mejia JA, Symmans WF, Gonzalez-Angulo AM, Hennessy B, Green M, et al: Response to neoadjuvant therapy and long-term survival in patients with triple-negative breast cancer. J Clin Oncol 26: 1275-1281, 2008

45. Li X, Yang J, Peng L, Sahin AA, Huo L, Ward KC, O'Regan R, Torres MA and Meisel JL: Triple-negative breast cancer has worse overall survival and cause-specific survival than non-triple-negative breast cancer. Breast Cancer Res Treat 161: 279-287, 2017.

46. Cailleau R, Olive M and Cruciger QV: Long-term human breast carcinoma cell lines of metastatic origin: Preliminary characterization. In vitro 14: 911-915, 1978

47. Chavez KJ, Garimella SV and Lipkowitz S: Triple negative breast cancer cell lines: One tool in the search for better treatment of triple negative breast cancer. Breast Dis 32: 35-48, 2010.

48. Sweeney EE, McDaniel RE, Maximov PY, Fan P and Jordan VC: Models and mechanisms of acquired antihormone resistance in breast cancer: Significant clinical progress despite limitations. Horm Mol Biol Clin Investig 9: 143-163, 2012.

49. Jung HJ, Park JY, Jeon HS and Kwon TH: Aquaporin-5: A marker protein for proliferation and migration of human breast cancer cells. PLoS One 6: e28492, 2011.

50. Ahmad AE, Khajah MA, Khushaish S and Luqmani YA: Aquaporin expression in breast cancer and their involvement in bleb formation, cell motility and invasion in endocrine resistant variant cells. Int J Oncol 56: 1014-1024, 2020.
51. Wei M, Yu H, Cai C, Gao R, Liu X and Zhu H: MiR-3194-3p inhibits breast cancer progression by targeting Aquaporin1. Front Oncol 10: 1513, 2020.

52. Zhu F, Chen L, Zhou Y, An J, Wu Z, Hu J, Ma Z and Cao F: Cellular-mesenchymal to epithelial transition factor upregulates aquaporin 3 expression in human breast cancer cells. Res Sq, 2020.

53. Snyder KK, Van Buskirk RG, Baust JG and Baust JM: Breast cancer cryoablation: Assessment of the impact of fundamental procedural variables in an in vitro human breast cancer model. Breast Cancer (Auckl) 14: 1178223420972363, 2020.

54. Livak KJ and Schmittgen TD: Analysis of relative gene expression data using real-time quantitative PCR and the 2(-Delta Delta C(T)) method. Methods 25: 402-408, 2001.

55. Skehan P, Storeng R, Scudiero D, Monks A, McMahon J, Vistica D, Warren JT, Bokesch H, Kenney S and Boyd MR: New colorimetric cytotoxicity assay for anticancer-drug screening. J Natl Cancer Inst 82: 1107-1112, 1990.

56. Littrup PJ, Jallad B, Chandiwala-Mody P, D'Agostini M, Adam BA and Bouwman D: Cryotherapy for breast cancer: A feasibility study without excision. J Vasc Interv Radiol 20: $1329-1341,2009$.

57. Cazzato RL, de Lara CT, Buy X, Ferron S, Hurtevent G, Fournier M, Debled M and Palussière J: Single-centre experience with percutaneous cryoablation of breast cancer in 23 consecutive non-surgical patients. Cardiovasc Intervent Radiol 38: 1237-1243, 2015

58. Fujita $Y$, Yamamoto $N$, Sobue K, Inagaki M, Ito H, Arima $H$, Morishima T, Takeuchi A, Tsuda T, Katsuya H and Asai K: Effect of mild hypothermia on the expression of aquaporin family in cultured rat astrocytes under hypoxic condition. Neurosci Res 47: 437-444, 2003

59. Salman MM, Kitchen P, Woodroofe MN, Brown JE, Bill RM, Conner AC and Conner MT: Hypothermia increases aquaporin 4 (AQP4) plasma membrane abundance in human primary cortical astrocytes via a calcium/transient receptor potential vanilloid 4 (TRPV4)- and calmodulin-mediated mechanism. Eur J Neurosci 46: 2542-2547, 2017.

60. Papadopoulos MC and Saadoun S: Key roles of aquaporins in tumor biology. Biochim Biophys Acta 1848: 2576-2583, 2015.

61. Dajani S, Saripalli A and Sharma-Walia N: Water transport proteins-aquaporins (AQPs) in cancer biology. Oncotarget 9: 36392-36405, 2018.

62. Abir-Awan M, Kitchen P, Salman MM, Conner MT, Conner AC and Bill RM: Inhibitors of mammalian aquaporin water channels. Int J Mol Sci 20: 1589, 2019.

63. Prevette LE, Mullen DG and Holl MM: Polycation-induced cell membrane permeability does not enhance cellular uptake or expression efficiency of delivered DNA. Mol Pharm 7: 870-883, 2010.

64. Tomita Y, Dorward H, Yool AJ, Smith E, Townsend AR, Price TJ and Hardingham JE: Role of Aquaporin 1 signalling in cancer development and progression. Int J Mol Sci 18: 299, 2017.

65. Taurin S, Allen KM, Scandlyn MJ and Rosengren RJ: Raloxifene reduces triple-negative breast cancer tumor growth and decreases EGFR expression. Int J Oncol 43: 785-792, 2013.

66. Chong W, Zhang H, Guo Z, Yang L, Shao Y, Liu X, Zhao Y, Wang Z, Zhang M, Guo C, et al: Aquaporin 1 promotes sensitivity of anthracycline chemotherapy in breast cancer by inhibiting $\beta$-catenin degradation to enhance TopoII $\alpha$ activity. Cell Death Differ 28: 382-400, 2021

67. Han Z and Patil RV: Protein Kinase A-dependent phosphorylation of aquaporin-1. Biochem Biophys Res Commun 273: $328-332,2000$.

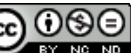

This work is licensed under a Creative Commons Attribution-NonCommercial-NoDerivatives 4.0 International (CC BY-NC-ND 4.0) License. 